\title{
INTERROGATIONAL TORTURE AS AN ABUSE OF HUMAN RIGHTS IN THE FIGHT AGAINST TERRORISM IN NIGERIA: AN ETHICAL EVALUATION
}

\author{
Chidiebere Obi* \\ \& \\ Uchenna Ezeogu* \\ http://dx.doi.org/10.4314/og.v13i 1.7
}

\begin{abstract}
Amnesty international had in its several reports accused the Nigerian military of using torture (which takes several inhumane forms) in her effort to defeat the Boko-Haram terrorist group. Sequel to this, it (amnesty international) usually recommends the criminalization of torture in Nigeria and the trial of the senior Nigerian army officers for sanctioning such. This is because Torture has long been prohibited by so many world's charters such as; the Geneva Conventions, the UN convention against Torture and other cruel, inhuman or degrading treatment or punishment, the European convention for the prevention of Torture and Inhuman or Degrading Treatment or Punishment among other international treaties on the abolishment of torture to which almost all the countries in world (including Nigeria) are all signatories. The paper ethically evaluates this call side by side the fight against terrorism thereby considering questions like: just as every law contains some exceptions; can we talk about exceptions in the laws prohibiting torture? Are there circumstances where interrogational torture may be considered as a necessity and therefore, justifiable? What are the arguments for and against torture? Since torture is considered as an abuse of human right; what happens where there is a clash of human rights (more especially, if a party to this clash has made himself less a human by posing as a threat to other persons' rights?) In considering theses questions, the paper concludes that the general call for the prohibition of interrogational torture should also take into account the peculiarities (such as the "ticking bomb scenario") involved in the fight against terrorism where the use of interrogational torture may be considered prudential.
\end{abstract}


Keywords: Human rights, Torture, Interrogational torture, Terrorism, Terrorist

\section{Introduction}

Human rights are "the basic rights and freedoms to which all human are considered to be entitled, often held to include rights to life, liberty, equality, and a fair trial, freedom from slavery and torture, and freedom of thought and expression." As a result of the perceived injustices and atrocities against the human person during the World War II, human rights were legalized in 1948 by the United Nations Universal Declaration of Human Rights. It was sequel to this that torture was prohibited and criminalized by many world's charters and conventions.

It is important to note that even though that virtually all the countries in the world are signatories to the above prohibitions on torture, some countries are yet to criminalize the act of torture. In Africa for example, out of the fifty four African Countries only nine have criminalized torture in their local legislations. These are Algeria, Burundi, Cameroon, Egypt, Equatorial Guinea, Madagascar, Mauritius, Tunisia and Uganda. ${ }^{2}$ It was against this backdrop that the Amnesty International has been raising alarm on the use of torture in the Nigerian Military's fight against insurgency. For instance, Amnesty International's February 2014 report on cases of torture in Nigeria states:

Amnesty International's ongoing research since 2008 indicates that the police and the military routinely use torture and other forms of ill-treatment as means of extracting information from suspects and also to break the spirit of the suspects or detainees. Moreover, the information or "confessions" extracted from detainees is in many cases, used in court as evidence. This is contrary to national and international law. The scale of the use of torture and other ill-treatment is increasingly alarming. ${ }^{3}$ 
Nigeria, since 2009, has been fighting to forestall the wanton destruction of lives and properties by the Boko Haram insurgency and has being criticized by some international bodies such as the Amnesty International for using some inhumane means like torture in this fight. An interaction with some military personnel reveals some mind boggling peculiarities. For instance, a suspect who was caught with cogent and obvious evidence of having a clue to stopping an imminent terror attack that will destroy hundreds of innocent lives but remains unwilling to divulge such information. Here, the military has the responsibility of protecting the lives and properties of the people and at same time to avoid inhumane treatment such as torture. The question will be; what do they do to this recalcitrant suspect? To answer this question, one must first of all, ethically evaluates the available options. To do this, we will first of all trace some of the cases where human rights have been abused by the use of torture in Nigeria and also consider some of the arguments for and against torture. This will then create a platform for the ethical evaluation of torture.

\section{Instances of Human Right Abuses in Nigeria}

Once the question of human right abuse is raised in relation to the fight against insurgents in the North-east Nigeria, one source that always comes to mind is the Amnesty International report. The executive summary of Amnesty International report posits that in the course of security operations against Boko Haram in the North-east Nigeria, Nigerian military forces have extra-judicially executed more than 1,200 people; they have arbitrarily arrested at least 20,000 people, mostly young men and boys; and have committed countless acts of torture. ${ }^{4}$ The report which was based on empirical study has it that, hundreds, if not thousands of Nigerians have become victims of enforced disappearance; and at least 7,000 people have died in military detention as a result of starvation, extreme overcrowding and denial of medical assistance..$^{5}$ Amnesty International Report has it that these acts committed in the context of a non-international armed conflict, constitute war crimes for which military commanders bear both individual and command responsibility, and may amount to crimes against humanity. ${ }^{6}$ 
Instances of Nigerian military extra-judicial killings according to Amnesty International: the report has it that one of the most horrific mass extra-judicial executions by the military happened on $14^{\text {th }}$ March 2014 in Maiduguri, Borno state Nigeria. In the aftermath of a Boko Haram attack on the military detention facility at Giwa barracks during which the detainees were released, the military killed at least 640 men and boys, most of them recaptured detainees. ${ }^{7}$

Other cases of mass extra-judicial executions documented by Amnesty International include the execution of 64 detainees in Presidential Lodge (Guardroom) detention facility in Damaturu, Yobe state Nigeria on the $18^{\text {th }}$ April 2013 and the killings of at least 185 people during a "mop-up" operation in Baga on 17 $7^{\text {th }}$ April 2013. In some cases, the bodies of executed detainees were returned to their families, usually dumped near the houses or on the outskirts of the villages. In other cases, the families were never officially informed of the deaths of their relatives and found out about the executions from released detainees or eyewitnesses. In many cases, they never found out at all. ${ }^{8}$

The report also narrated the story of one Saleh Jega (not his real name), a 25-year-old carpenter from Maiduguri, who was arrested along with 18 others on the $25^{\text {th }}$ November 2012 during a cordon-and-search operation in Gwange, and taken to Giwa Barracks. He escaped after more than 15 months when Boko Haram attacked the barracks. His story has it that some days 50 or up to 80 people died, mainly of starvation and thirst. Out of the 19 he was arrested with, only four survived. He narrated his story thus:

We have a sense that they just want us to die. Many people died in the cells. Any time we were denied water for two days, 300 people died (in those two days) sometimes we drink people's urine, but even the urine you at times could not get. Every day they died, and whenever someone died, we (the other detainees) were happy because of the extra space. And because we will be taken out, to take out the corpses and the military will give us water to wash 
our hands and when washing our hands, we drink the water. ${ }^{9}$

One major factor that ran through eyewitnesses or victims of military abuse reports is that, the victims were mostly tortured to admit their membership to the sect. The tortures were also aimed at eliciting information that will help the military foil future attacks from the Boko Haram sect. Before we can evaluate these reports from the Amnesty International, it will be of great importance for us to first briefly consider arguments and counter-argument given so far on the justifiability of torture.

\section{Torture Arguments}

The UN Convention against Torture and other Cruel, Inhuman or Degrading Treatment states:

The term torture means any act by which severe pain or suffering, whether physical or mental, is intentionally inflicted on a person for such purposes as obtaining form him or a third party information or confession, punishing him for an act he or a third person has committed, or is suspected of committing, or intimidating or coercing him or a third person, or for a reason based on discrimination of any kind, whether such suffering is inflicted by or at the instigation or with the consent or acquiescence of a public official or other person acting in an official capacity. ${ }^{10}$

It is important to state here that the above definition of torture is the working definition in this paper. With the high rate of terrorism in the world today, arguments and counter-arguments on torture have gained popularity. On one hand, some deductions from arguments against torture are:

a. Torture should not be allowed because it defies the dignity of the human person (this is considered as the basis). Here, 
the torturer is considered less moral while the tortured loses his dignity as a human person.

b.

Torture violates both the international and domestic laws thereby contradicting the binding nature of laws.

c. Exceptions to laws against torture can lead to abuse.

d. Information gotten through torture may not be trusted.

e. Torture can lead to double wrongs since it is using bad means to achieve an end of which the terrorist is guilty of.

f. Torture goes contrary to the legal maxim 'innocent until proven guilty'. Etc.

On the other hand, pro torture scholars also presented some features that can be deduced such as:

a. Prohibitions on torture are so absolute that they failed to foresee possible subsequent developments that may warrant flexibility and exceptionality.

b. Going by the recent surge in terrorism and kidnapping, torture may be considered as a means to the solution.

c. That torture presents a more realistic picture of man's effort in solving his existential problems than its prohibitions which are highly myopic, abstract and utopian.

d. Given a scenario where many persons with 'dignity' are in danger of losing their lives if just one or two person (s)'s (who hold (s) the key to stopping this danger) dignity is protected; that torture in this case is not only encouraged but also justifiable. i. e., what do we do if 'right to life' will be endangered by a strict adherence to human dignity? Etc.

Scholars that argued in support of torture, always have recourse to 'ticking-bomb scenario'. According to Richard H. Corrigan, 'tickingbomb scenario' can be seen as:

...a hypothetical situation that supposes definite devastating consequences for a large number of innocent people, if nothing is done to prevent the immanent detonation of a terrorist bomb. The authorities have in their custody a detainee who is 
aware of the location of the explosive device, but he refuses to co-operate in the provision of information essential to its discovery and disarmament. The question is: would the authorities be morally justified in the use of torture to ensure that the catastrophic explosion is averted? ${ }^{11}$

A utilitarian approach to ticking bomb argument was held by Mathuna; "the ticking bomb argument is basically a utilitarian argument. The good consequences of discovering the sought-after information outweigh the bad consequences of torture." 12

Using the consequentialist view, Corrigan further states:

Consequentialists have argued that an unexceptionally prohibitive stance on torture is untenable, both morally and practically. When one adopts such a position one does not allow that there may be mitigating circumstances in which the use of otherwise uncondonable measures is morally justifiable and practically expedient. In the tickingbomb scenario, the degree of the threat and the timeframe in which a solution must be secured mean that, irrespective of what the authorities proceed to do, an evil will occur. It is assumed that it is certain that the bomb will explode and there will be significant civilian casualties if they do not extract the information from the terrorist. The consequentialist argues that the use of torture is a legitimate tool of interrogation in such extreme circumstances, as it is the lesser of two evils. ${ }^{13}$

In the light of the above arguments, we can at this juncture ask: are these traces of torture as reported by the Amnesty International avoidable or necessary considering the gorilla nature of the warfare? Is there a better alternative to the torture method? Is there substantial evidence that those who were tortured are innocent? And what if there was substantial evidence that they were not 
innocent? We will now turn to the ethical evaluation of these questions and more.

\section{Ethical Evaluation}

With the Amnesty International report on the traces of torture as an abuse of human rights in the fight against terrorism by the Nigerian Military (even though the Nigerian Military and Government have severally queried the authenticity and certainty of such reports), it then calls for an ethical evaluation of torture side by side the intricacies of fighting terror. This call was necessitated by the nature of torture which can be classified as a human act which is the subject matter of Ethics as a branch of philosophy. To do this, we shall employ some selected ethical theories such as: Kantianism and Situationism.

Kant formulated duty ethic that has three formulations but for the purpose of this paper, we will apply only two of these formulations to torture. Kant believes that an act is morally praiseworthy only if done neither for self-interested reasons nor as the result of a natural disposition, but rather from duty. ${ }^{14}$

\section{Universal Law formulation}

"Act only according to that maxim by which you can at the same time will that it should become a universal law." This formulation enjoins one to always assume his actions to be universal laws thereby ensuring that he refrains from those acts he wouldn't want other persons to carry towards him. It simply means: 'do unto others what you will want them to do unto you'.

Consider a terrorist who sets a ticking bomb that has the capacity of killing thousands and was captured by the Law Enforcement Agents who are in possession of the evidence that shows that the terrorist is the culprit; this terrorist shows the unwillingness to divulge details on how to stop the bomb from exploding; considering the limited time available, the Law Enforcement agents used interrogational torture as the only means available to elicit information and eventually stopped the bomb. How do we justify this act using Kantian universal law formulation?

Applying this formulation to the terrorist's act, then the universal law that can be generated from his act of wanting to kill 
thousands of people using bomb (no matter the goal behind such act) will be: 'whenever one wants to pursue a goal, the person should use human life (as many as possible) as a bait and means'. This has already defeated the purpose of this formulation. If this happens to be a standing universal law, then, torturing a terrorist is not only justifiable but also a prudential application of such a law (since such does not necessarily lead to his death).

Applying this Kantian formulation to the act of torture by the Law Enforcement Agents, we can generate a universal law: 'whenever one who has the responsibility of protecting the lives and properties of people is faced with the situation of saving many lives by torturing an unrepentant and mean terrorist (who is responsible for endangering these innocent lives) as the only means of doing so, he should not hesitate from doing so'. One can argue that if given options to choose between these two laws, people will definitely adopt the second because it's more humane than the first. The second will even serve as deterrence to the would-be terrorist which is one of purposes of laws.

\section{Kingdom of Ends formulation}

"So act as if you were always through your maxims a law-making member in a universal kingdom of ends". This formulation establishes the person as a free and autonomous being capable of making universal laws and seeing other persons as equals. This formulation presents an image of the human person who should not be tortured no matter what simply because he/she belongs to the 'kingdom of ends' and should be treated accordingly. But going by the example given above; where a terrorist was holding thousands of people ransom, one can argue that the terrorist has disassociated himself from the Kant's kingdom of ends by his action. Sequel to this, he (the terrorist) is less an "end" and incapable of making a universal law through his action. The questions here are: does the membership of this kingdom of end make the human person an 'absolute end' absolved from the responsibility and consequences of his/her actions? Do we stick to the Kant's 'universal kingdom of ends' and treat the terrorist as a member of this kingdom at the expense of the ideal members of this kingdom of ends (the innocent people the terrorist was holding ransom)? Or do we torture this 
terrorist to elicit details on how to save the innocent lives since he willingly made himself less an 'end' and less dignified? Assuming if these two options were before Kant, one may argue that he will opt for the second since by so doing, one will automatically become a law-maker for the kingdom of ends.

We must give credence to Kantianism for pointing out the intrinsic worth of the human person as a being with dignity and rights and to be treated as such. Kant's concept of 'duty' is also very crucial because it points out the obligatory nature of morality. So it is a matter of obligation that good must be done not because of any selfish interest but because it is a duty that man should always do good. On this, any act that degrades and dehumanizes the human person is not performed on duty therefore, becomes condemnable and should be refrained from. In the light of this, any soldier that tortures a suspect without any cogent evidence (as argued above) is grossly violating Kant's duty ethic and by extension, the rights and dignity of the human person.

\section{Situationism}

Situation ethic is a teleological ethical theory that was popularized by Joseph Fletcher. Situationism believes in the universal moral laws but fails to recognize them as absolute and indispensables. Laws can guide one to moral decision making but can be abandoned given to situations. Situational approach to decision making is circumstantial and not prescriptive. Situationism tilts towards the maximization of love. It preaches that nothing is intrinsically good or bad rather, what makes things good or bad is situation. The only yardstick for measuring the good act in a situation is love. Therefore, what may seem to be bad (in terms of code ethics) may be justifiable under situationism provided that it maximizes love. Situationism by nature is pragmatic, relative, positive and personal.

In the light of the above, situation ethic is not kicking against the law but its absoluteness. It is saying that law should take into consideration the peculiarities and concreteness of man. There are always some unforeseen circumstances that maybe invincible at the time of making a law; therefore, there should always be rooms for exceptions. Sequel to this, if a situation demands that we can maximize love by disobeying a law, we should not hesitate from 
doing so and if obeying the law will help maximize love, then, law should be obeyed. Love is the only thing that is absolute.

Although it is not the intention of this paper to engage in the detailed analysis of these ethical theories, but it is necessary to state at this juncture that Situationism as ethical theory has faced so many criticisms such as its ambiguous concept of love, its disregard to the means to the maximization of love, its contradiction with the Christian understanding of love, its imposition on man as an omnipotent being capable of doing the most loving thing etc. We can now turn to the application of situationism.

A glance on situationism can easily reveal that it is Janusfaced. This is because; a terrorist or kidnapper that is holding thousands lives hostage may claim he is acting out of love (maybe to protest against the injustice meted on his country) as well as a law enforcement agent who tortures a terrorist in order to get information that will help free these thousands. This is because of the porous nature of Fletcher's concept of love. The quality of the love to be maximized and the means to actualizing this must be questioned. It is against natural justice to sacrifice innocent lives with dignity as a means to maximizing love. This is because according to Fletcher, "justice is love distributed." 15 Therefore, the person that maximized love between the terrorist and the Law enforcement agent is the later.

A critical mind can argue that love does not use one as a means of saving many. The parable of the lost sheep buttresses this point where a shepherd left his ninety nine sheep in search of one that went missing. Therefore, torturing a suspected terrorist in order to save many contradicts this view. But we may quickly add here that the above stated parable did not tell us the state of the ninety nine sheep; that is, whether they were in danger or not. We believe that if the ninety nine were in danger, the shepherd will not hesitate from saving them first instead of leaving them in search of the missing one that may have stubbornly left the folk of the ninety nine. Another point to be considered here is the situationism's outright antagonism against making a law absolute. We can agree with the situationists by saying that the absolute ban on torture fails to foresee circumstances and situations that may warrant torture. 
Therefore, in line with recent developments such as the high rate terrorism, it calls for a re-look.

So far, we have been able to prove (using the selected ethical theories) that torturing the human person is condemnable considering the fact that the person is a being that should be treated with dignity and as a being with rights. But we also considered some extenuating circumstances (using ticking bomb scenario) where interrogational torture may be seemingly permissible.

\section{Conclusion}

From the foregoing, the above instances of torture and wanton killing of people by the Nigerian Army in the fight against terror (if true and established) as presented by the Amnesty International are all outright violations of the human dignity and this research condemns such. Due to this, the research recommends that countries (Nigeria for instance) that are yet to criminalize this heinous crime should do so but with a caveat that interrogational torture may be used in the 'ticking bomb scenario' where there is a clear evidence (for instance a CCT Camera footage or a reliable witness) that the torture victim holds the information that will lead to saving innocent lives but refuses to do so; therefore, interrogational torture maybe used as a last resort considering the limited time available. This is because, at that level, the tortured possesses less rights and dignity than the innocent lives in danger. This may appear as a thought experiment but we should not rule out its possibility.

One may ask: what if the evidence provided happens to be false? What if the tortured refuses to divulge this information even after being tortured? Does this 'ticking bomb' not encourage 'slippery slope' (abuses)? We can react to these questions by referring to the criminalization of taking of another person's life (murder); but one is legally pardoned when killed in self defense and the only way to prove this is through the judicial procedures. Therefore, the above questions raised on interrogational torture in the 'ticking bomb scenario' will be taken care of through the judicial procedures. The court will decide on whether the law enforcement agent acted on false and fabricated evidence or not. If at the end of the day the information elicited from the tortured facilitated the saving of these innocent lives, then, the officer is exonerated from 
any crime but if the officer only used torture abusively, then, the law will take its course. On the question on whether we are sure that the tortured will divulge any useful information, we can use the analogy of a police officer who shot (in self defense) a suspected criminal simply because the suspect tried pulling out a weapon from his pocket but it was later discovered that the suspect's gun was only a toy. Here, the police officer shot the suspect in self defense because that was his only option to saving his life and also because of the limited time available for him to check if the suspect's gun is loaded or not. This can be applied to interrogational torture in the 'ticking bomb scenario' because at that level, the law officer has limited time to save the innocent lives and also considering the evidence at his disposal, interrogational torture appears to be the last resort.

Finally, this paper is believed to serve as a guide for the Amnesty International and other bodies saddled with the responsibility of reporting traces of torture and other abuses against the human person. The onus is now on such bodies to take into consideration the exigencies involved in the fight against terror thereby understanding situations where the use of torture maybe considered a necessity.

*Chidiebere Obi, PhD, Department of Philosophy, Nnamdi Azikiwe University, Awka, ccy.obi@unizik.edu.ng

*Uchenna Ezeogu, PhD, Department of Philosophy, Nnamdi Azikiwe University, Awka, ucheinchrist2000@gmail.com 


\section{References}

1. http://www.thefreedictionary.com/human+rights. Retrieved on $7 / 4 / 16$.

2. L. Umar (2012), Enhancing Torture Prevention in Africa, www.achpr.org/files/news/2012/08/.../dr._umar_lydias_presen tation.doc. Retrieved on 30/9/15.

3. Amnesty International, Nigeria: Torture, cruel inhuman and degrading treatment of detainees by Nigerian security forces: Amnesty International's written statement to the 25th session of the HN Human Rights Council, https://www.amnesty.org/download/Documents/.../afr4400120 14en.pdf, 2014. Retrieved on 29/9/15.

4. "Stars on their shoulders Blood on their Hands, War Crimes committed by the Nigerian Military" Amnesty International Report http://www.amnesty.org/download/Document/AFR4416612015 ENGLISHpdf. Retrieved on 6/5/16.

5. Ibid.

6. Ibid.

7. Ibid.

8. Ibid.

9. Ibid.

10. UN Convention against Torture and other Cruel, Inhuman or Degrading Treatment pt. 1, art. 1 (1984), http://www.un.org/documents/ga/res/39/a39ro46.htm.

Retrieved on $14 / 5 / 15$.

11. R. Corrigan (2008), 'Hiding behind the Hypothetical: The Unjustifiability of Torture', Electronic Journal for Philosophy/, www.academia.edu/620479/Hiding_Behi... , Retrieved on $14 / 5 / 15$.

12. D. P. O'Mathuna, The ethics of torture in 24: Shockingly banal, www.snow.edu/../ethicsoftorture.pdf, Retrieved on 20/4/15.

13. Corrigan, R. H. P. 45.

14. C. M. Ekwutosi (2006), Basic issues in Ethics. Anambra: Rex Charles \& Patrick Ltd, p. 42.

15. J. Fletcher (1966), Situation Ethics. London: SCM Press, P.18. 